\title{
Hazard Analysis Critical Control Point (Haccp) Assessment of Regulated Premises: An Assessment of Standard Hotels in Ilorin Metropolis
}

\author{
Habeeb Modupe Lateefat ${ }^{1,}$, , Henry O. Sawyerr ${ }^{1}$, Alabede Mubarakat ${ }^{1}$, \\ Abdulrauf Olanrewaju Yusuf ${ }^{1}$, Adiama Babatunde Yusuf ${ }^{1}$, Olaniyi Opasola ${ }^{2}$, Adeolu Adedotun ${ }^{1}$, \\ Usman Suleiman ${ }^{2}$ \\ ${ }^{1}$ Department of Environmental Health Science, Kwara State University, Malete, Kwara State, Nigeria \\ ${ }^{2}$ Department of Environmental Management and Toxicology, Kwara State University, Malete, Kwara State, Nigeria
}

Email address:

atandalateefah@gmail.com(H.M. Lateefat)

${ }^{*}$ Corresponding author

\section{To cite this article:}

Habeeb Modupe Lateefat, Henry O. Sawyerr, Alabede Mubarakat, Abdulrauf Olanrewaju Yusuf, Adiama Babatunde Yusuf, Olaniyi Opasola, Adeolu Adedotun, Usman Suleiman. Hazard Analysis Critical Control Point (Haccp) Assessment of Regulated Premises: An Assessment of Standard Hotels in Ilorin Metropolis. Journal of Health and Environmental Research. Vol. 4, No. 2, 2018, pp. 56-68. doi: $10.11648 /$ j.jher.20180402.13

Received: April 25, 2018; Accepted: May 24, 2018; Published: June 12, 2018

\begin{abstract}
Food safety issues in developing countries are mostly centered on illnesses that are linked to poor hygiene but food hygiene in hotels remains an area of concern. Hospitality Industries are known to provide food, drink or accommodation to people who are away from home. Food poisoning can arise from public eating places like hotels and restaurants as a result unhygienic food preparation. The purpose of the study was to assess the HACCP compliance of standard hotels in Ilorin metropolis, Kwara state. Purposive sampling was used with laboratory component carried out in five standard hotels in Ilorin metropolis and the hotels with alphabets. Data were obtained through on-site observation using checklist and face to face interview.15 food samples (fried rice, white rice), 12 hand swab samples and 7 seven water samples were collected to determine the hygienic level of the food. Data collected were analyzed using descriptive statistics and the results were presented using charts and tables. Proteus mirabilis, Proteus vulgaris, S. aureus, Klebsiella pneumonia, Pseudomonas aeruginosa and Candida albicans were isolated in various foods, water and hand swab. The total viable count was below $10^{5} \mathrm{CFU} / \mathrm{g}$ in all the seventeen (17) samples with $1.71-86.82 \times 10^{2} \mathrm{CFU}$ in food, $1.65-12.2 \times 10^{2} \mathrm{CFU}$ in hand swab and $10.6323 \times 10^{2} \mathrm{CFU}$ in water samples. From the findings, the food samples found to be within the marginal aerobic colony count limits according to the International Commission for Microbiological Specification for Foods (ICSMF, 1978). This implies that, though the food samples were within limits of acceptable microbiological quality, there might have been possible hygiene problems either in the preparation of the food or in handling of the food. From the checklist, it was revealed that majority $(95 \%)$ of the hotels (B, C, D, E, F, G, H, I) did not meet the HACCP requirement. The study revealed that the concept of HACCP was not understood and that this could be impacting on the general food hygiene standards and food-handling practices of personnel. Therefore, there is need to implement HACCP system to prevent food poisoning outbreaks and the hotels can easily adapt the strategy only if law enforcers could put strict monitoring in place.
\end{abstract}

Keywords: HACCP, Hotels, Food Handlers

\section{Introduction}

Food for human consumption should be protected from contamination at all times especially when there are frequent outbreaks of food borne illnesses. According to the world health organisation and United Nation Children Education Funds (WHO/UNICEF) Joint Monitoring Program (JMP) (accessed in 2013) for water and sanitation only 58 percent of the country's 160 million people have access to potable 
water. Food safety issues in Africa are mostly centered on illnesses that are linked to poor hygiene but food hygiene in homes, schools, food industries and markets remains an area of concern. Symptoms of foodborne illnesses such as vomiting, diarrhea, fever are regarded as "common diseases" and everyone seems to know the cure and requires only going to the "chemist" to purchase self-prescribed medication. Consequences of food borne illness include adverse effects on trade and tourism, loss of earnings and productivity, unemployment and litigation. In recognition of the above, the Food Safety Act (2016), has been revised and the check list is now designed on the lines of Hazard Analysis and Critical Control Point (HACCP), to meet international standards.

HACCP is an evaluation system that is developed to assess, implement and control the threats of contamination in food service industry. It international acceptance has become the basis of discussion on food safety and prevention of chemical, biological and physical contaminants, etc. It is a program that ensures the quality, safety and hygienic practices carried out in the foods and drinks served. Hazard Analysis and Critical Control Point (HACCP) is a system that has been around since the late 1960's. Originally HACCP was designed for National Aeronautical Space Agency (NASA) and the space program to ensure a safe product by attempting to eliminate or reduce end point testing after processing. All the operations carried out in the kitchen are controlled by part of the procedures contained in the HACCP system. Therefore these procedures are integrating all the operations involving food and drinks. The biggest advantage of HACCP over the other systems is that it pre-empts all the activities in the food process thus reducing risks in food-borne diseases.

Many studies have found that diarrhoeal illnesses are affecting travelers. In 1998, Travel Weekly reported in 1998, that of $63 \%$ of persons who experienced illness while traveling, 35\% classified their symptoms as gastro-intestinal. MacLaurin quoting from Cheung et al., (2000) suggests that $17 \%$ of 100 UK citizens reported food-borne illnesses while traveling internationally within the last 5 years. She also went on to say that $35 \%$ of 290 international air travelers had suffered from food-borne illnesses; quoting from Delgado's (2000) study, she also reported that $38 \%$ of a sample of 200 German and UK Vacationers had experienced food-borne illnesses while traveling. MacLaurin and Tanya, (2001), Steffen et al., (1996-1997) found that 23.6\% of tourists suffered from Travellers' Diarrhea during their stay in Jamaica. Worldwide, there were a total of 816 food borne disease outbreaks, with 80, 682 reported cases, from 1927 until the first quarter of 2006, in which food handlers were implicated in the spread of the diseases (Greig et al., 2007). Studies on food safety have tended to focus on regulations and measures required to develop and enforce the food safety regulations, education and technical sophistication to be applied by food processors for HACCP to be accomplished (Corlett, 1998). This may suggest a need for a study to assess HACCP compliance by hotels if such food safety system is not available, the need to investigate the possibility of introducing a HACCP system, for hotels, aroused from the fact that a HACCP system must be developed by each sector and tailored to their individual products, processing and distribution conditions.

In a survey done by MacAuslan (2003), it was reported that the majority of food businesses do not have satisfactory training policies for their staff. Too much reliance is placed upon obtaining a certificate rather than attention being paid to achieving competency in food hygiene practice. It was suggested that more emphasis and resources need to be diverted towards assisting managers to become highly motivated food hygiene managers who develop and maintain a food safety culture within their businesses.

Murat Bas et al., (2000) have evaluated knowledge attitudes and practices concerning food safety issues among food handlers in Turkey. They conducted face to face interview and administrating questionnaire of the 764 food handlers who responded $9.6 \%$ were involved in touching or distributing unwrapped foods routinely and use protective gloves during their working activity. The study demonstrated that food handlers in Turkish food businesses often have lack of knowledge regarding the basic food hygiene (critical temperatures of hot or cold ready to eat foods, acceptable refrigerator temperature ranges and cross-contamination etc.). There is an immediate need for education and increasing awareness among food handlers regarding safe food handling practices.

Anita Eves and Panagiota Dervisi (2005) has studied 'Experiences of the implementation and operation hazard analysis critical control points in the food service sector 'This study explored experiences of implementation and operation of hazard analysis critical control points (HACCP) in food service sector. Experiences highlighted a number of barriers to the successful implementation and operation of HACCP, and also perceived benefits. Barriers included difficulties of identifying hazards, inadequate knowledge, time related issues related to monitoring and recording, excessive documentation, convincing staff of importance of the system, and increased costs. Perceived benefits included protecting the business from otherwise unforeseen problems and providing evidence of 'due diligence'. There was however, an attitude of compliance, rather than true recognition of the value of the system.

A lot of work has been done on the HACCP of street foods in Nigeria with the conclusion that most of them are prepared under unhygienic conditions. However, not much work has been published in the country on HACCP with regards to the hotel industry. Few studies done elsewhere in the hotel and restaurant industry have found that food contact surfaces are a great source of contamination.

This study was therefore conducted to assess HACCP implementation in 5 highly standard hotels in Ilorin metropolis to determine the compliance of the selected hotels with HACCP principles in reducing or eliminating hazards in their production and services. 


\section{Methods}

\subsection{Study Design}

The study that would be used is descriptive studies to assess HACCP as a strategy for quality control in the hotels. The design made use of experimental method of analysis to determine microbiological quality of food and water served in hotels and took a form of conclusive study which was based on laboratory and statistical methods.

\subsection{Study Area}

Ilorin is located on latitude $8030^{\prime} \mathrm{N}$ and Longitude 4
035'E with an area of about 100km 2 (Kwara State Diary 1997). The city is situated in the transitional zone between the forest and savanna region of Nigeria. The geology of Ilorin consists of Pre- Cambrian basement complex with an elevation that varies from $273 \mathrm{~m}$ to $333 \mathrm{~m}$ in the West having an isolated hill (Sobi hills) of about $394 \mathrm{~m}$ above sea level and $200 \mathrm{~m}$ to $364 \mathrm{~m}$ in the East. Oyegun, 1983 further asserted that a large part of Ilorin town is laid by sedimentary rock, which contains both primary and secondary laterites and alluvial deposits. The major river in Ilorin is Asa, which flows North-South direction dividing the plain into two, Western and Eastern part.

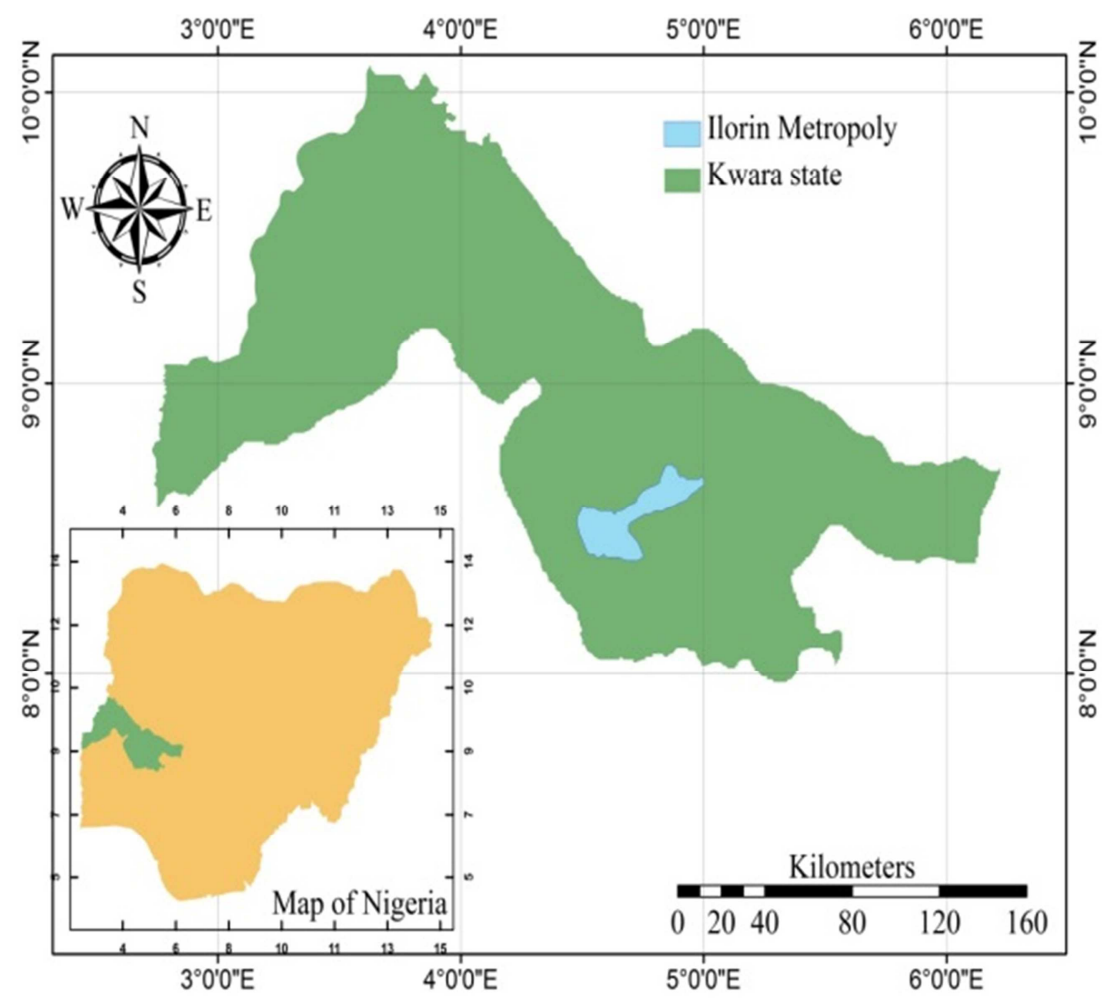

Figure 1. Map showing Kwara with indication of the study area.

\subsection{Sampling}

The sampling frame consisted of all hotels in a specific geographical section in the Ilorin. These hotels were classified using the Nigerian tourism development corporation grading and classification of hotels (5) Using purposive sampling method, a $70 \%$ sample of each hotel which met the inclusion criteria was studied.

\subsection{Hotel Classification}

Table 1. Hotel Classification.

\begin{tabular}{lll}
\hline Hotel & Classification & Ratings \\
\hline A & Standard & 4 star \\
B & standard & 3 star \\
C & standard & 4 star \\
D & standard & 3 star \\
E & standard & 3 star \\
F & substandard & 2 star \\
\hline
\end{tabular}

\begin{tabular}{lll}
\hline Hotel & Classification & Ratings \\
\hline $\mathrm{G}$ & substandard & $3 \mathrm{star}$ \\
$\mathrm{H}$ & substandard & $1 \mathrm{star}$ \\
$\mathrm{I}$ & substandard & $1 \mathrm{star}$ \\
\hline
\end{tabular}

\subsection{Observational Checklist Was Used to Collect Data on Practices Related to Food Hygiene and Safety}

Data on availability of equipment for hygienic practice was collected from all sampled hotels using an HACCP observation checklist. Critical elements to food safety and hygiene were listed on the observation checklist that formed the last part of the questionnaire. The researcher had to assess if the equipment was available, e.g. hand washing facilities, clean drying cloths etc. If these were available the answer, "maximum was circled it means the facilities or equipment's were completely functional and if minimum was circled by the researcher, means the facilities are completely functional, if not available was circled by the researcher, means the 
facility was not available. Observations have limitations in that they may be regarded as being subjective. In order to address this, observations of equipment available were collected by the researcher, health professionals trained in food hygiene. This would then be used to conclude that if a sink and soap were available, that hand washing was done. The actual observation of food preparation would be beneficial so as to confirm whether the knowledge and attitudes this is done expressed in the responses were in reality put into practice.

\subsection{Data Collection}

The food samples were bought into sterile plastic plate with covers, kept into a cold box containing ice packs and transported within an hour to the Genesis laboratory at Ogbomosho. These food samples were subjected to microbial analysis for colony count, characterization of bacteria and fungi, and antibiotic sensitivity. Also the swab stick will be dipped into a bacteriological peptone water and then use to swab the food handlers hand in which will be later dipped into the bacteriological peptone water, covered and taken to the laboratory for microbial assessment.

\subsection{Laboratory Methods}

\subsubsection{Culture method}

The materials submitted (water, swab sticks and food) were culture on to 3 culture media (Blood Agar, MacConkey Agar and Saboroud Dextrose Agar) incubated for 24hrs and 4days for bacteria growth and fungi growth respectively at $37^{\circ} \mathrm{C}$.

\subsubsection{Water Sample}

A Wire loop of $2 \mathrm{~cm}$ diameter was sterilized using Bunsen burner flame, it was allow to cool and dip into the water samples. The water was aseptically transfer to the 3 sterile culture media each and plated out by striking to obtain a district colony and was incubated at $37^{\circ} \mathrm{C}$ for $24 \mathrm{hrs}$ and the growth result read. Further analysis was then carried out on the isolate to determine the organism, colony count and sensitivity test.

\subsubsection{Swab Sample}

The swab stick where each smeared on the sterile culture media (blood agar, macconkey and saboroud dextrose agar). The primary inoculum was spread out to allow district colony growth. This was incubated at $37^{\circ} \mathrm{C}$ for $24 \mathrm{hrs}$ and 4 days and further microbial analysis carried out, (characterization, colony count, antibiotics sensitivity test).

\subsubsection{Food Samples}

$10 \mathrm{ml}$ of distilled water was added to each food samples and mix to obtain homogenous mixture of samples. Sterile wire loop was used to pick a volume of $(0.1 \mathrm{ml})$ and transfer to the Medias in used (macconkey agar, blood agar and saboroud dextrose agar). It was incubated for $24 \mathrm{hrs}$ and 4days and further microbial analysis carried out Characterization, Colony count and Sensitivity test.

\subsubsection{Characterization of Isolates}

Bacteria Isolate where identify to specie level using their morphological appearance color of colonies, growth pattern, biochemical test (catalase, coagulase, indole, sugar fermentation, oxidase, motility, urease test, citrate, nitrate etc.) and their Gram Staining reactions, fungal isolated where viewed with $\mathrm{KOH}$ (potassium hydroxide) for microscopy.

\subsubsection{Colony Count}

Bacteria and fungi count were obtain from direct culture and multiply by dilution factors where applicable to obtained the colony forming units $\mathrm{CFU} / \mathrm{ml}$ after $24 \mathrm{hrs}$ of incubation at $37^{\circ} \mathrm{C}$ and 4 days for fungi isolate.

\subsubsection{Antibiotics Sensitivity Test}

The Standardized disc diffusion method was used and the zone size interpreted in correlation to the one suggested by the National Committee for Clinical Laboratory Standards (NCCLS 1997).

\subsubsection{Disc diffusion Method}

A sterile wire loop was used to pick a colony of isolate and transfer to $5 \mathrm{ml}$ distilled water in a mccarthny bottle. This was mix to obtain a homogenous mixture and A Sterile swab stick was plunged into the mixture and the excess fluid was expressed out, The Swab stick was aseptically spread on the entire surface of a muller hinton agar plates. Antibiotics discs (Rapid Lab UK) were position aseptically on the surface using sterilized forceps and there after incubated at $37^{\circ} \mathrm{C}$ for $24 \mathrm{hrs}$ and Zone of inhibition were measured and classified/ interpreted as either sensitive or resistant using a measuring ruler as compare to (NCCLS Standard).

Table 2. Antibiotics used.

\begin{tabular}{|c|c|c|c|}
\hline Ofloxacin 5ug (OFL), & Ceftriaxone 30ug (CTR) & Ampicillin 30ug (AMP) & Gentamicin 10ug (GEN), \\
\hline Perfloxacin 5ug (PEF) & Cefuroxime30ug (CRX), & Augmentin 30ug (AUG) & Nitrofurantoin, 300ug (NIT) \\
\hline Ciprofloxacin 5ug (CPR) & Ceftazidine 30ug (CAZ) & Cloxacillin 5ug (CXC) & Tetracycline 10ug (TET) \\
\hline
\end{tabular}

The Following Antibiotics where used (Rapid Labs UK).

\subsection{Data Analysis}

Prior to data entry, and during the data collection period, the completed data was captured in Excel. The observational data was categorized for analysis. All numerical data was analyzed using descriptive statistics. Result was presented using frequencies, charts and tables. 


\section{Results}

\subsection{Observational Checklist}

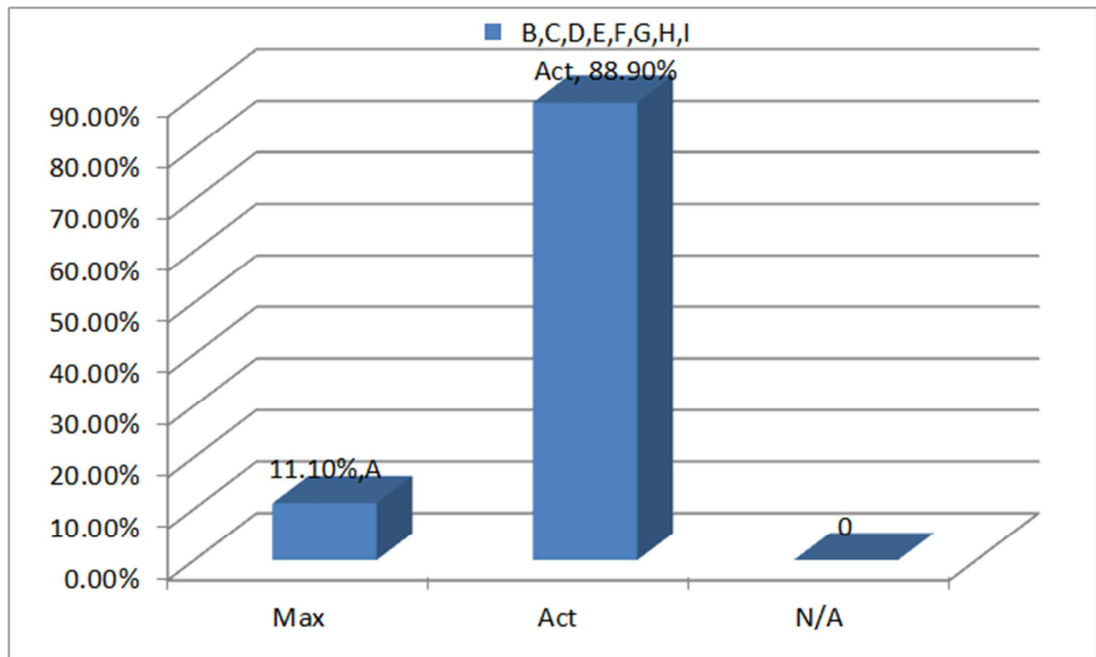

Figure 2. Percentage of hotels that take up proper food transportation.

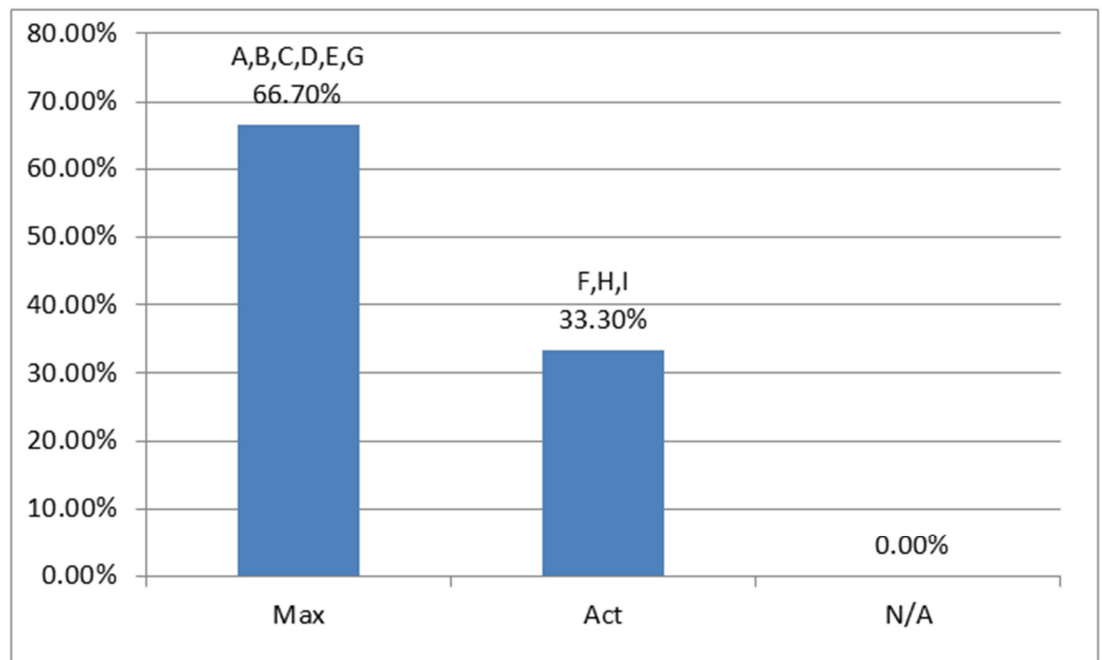

Figure 3. Percentage of hotels that prevent cross contamination.

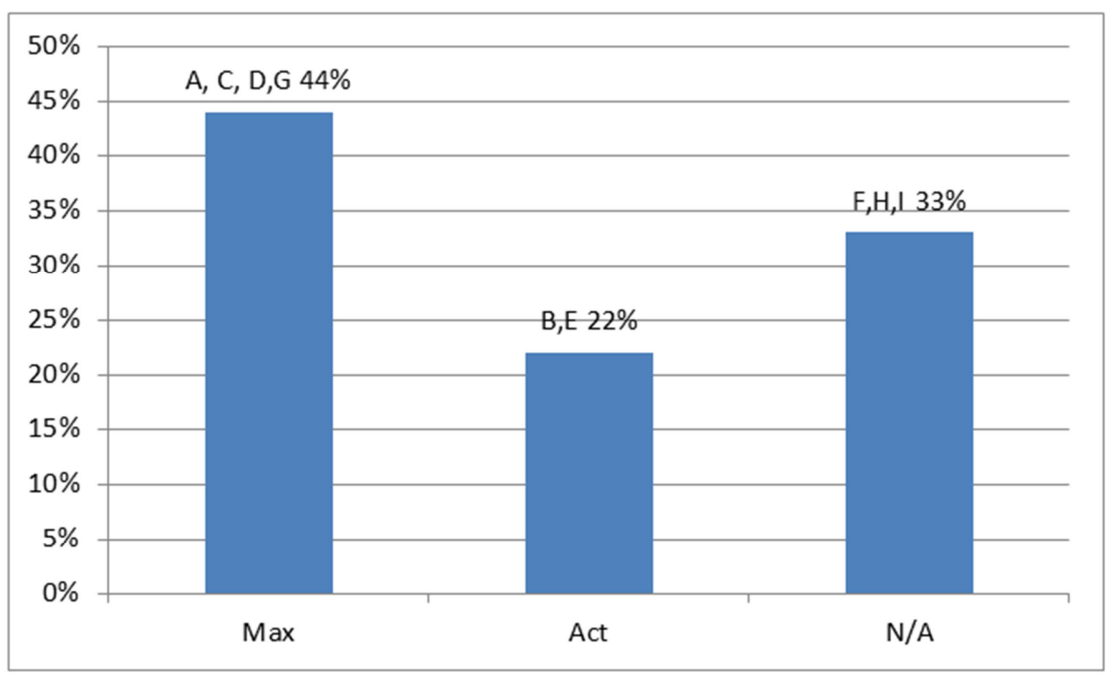

Figure 4. Percentage of hotels with trained food handlers. 

Regulated Premises: An Assessment of Standard Hotels in Ilorin Metropolis

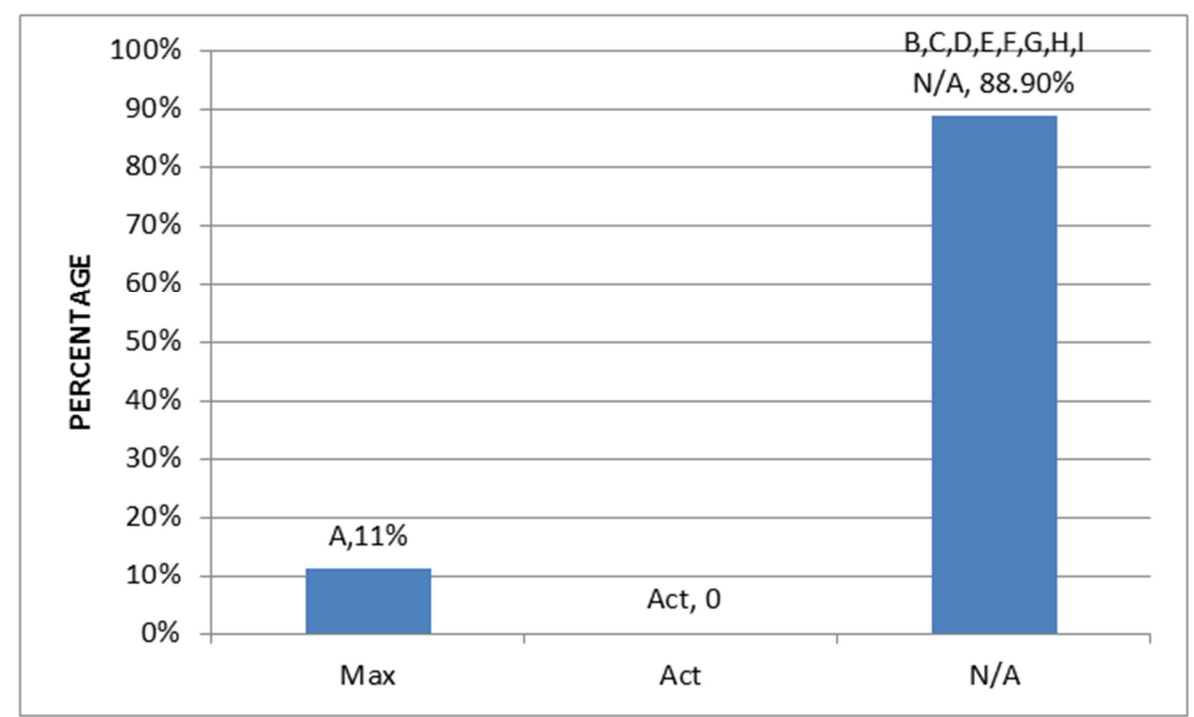

Figure 5. Percentage of food thawed in the right temperature.

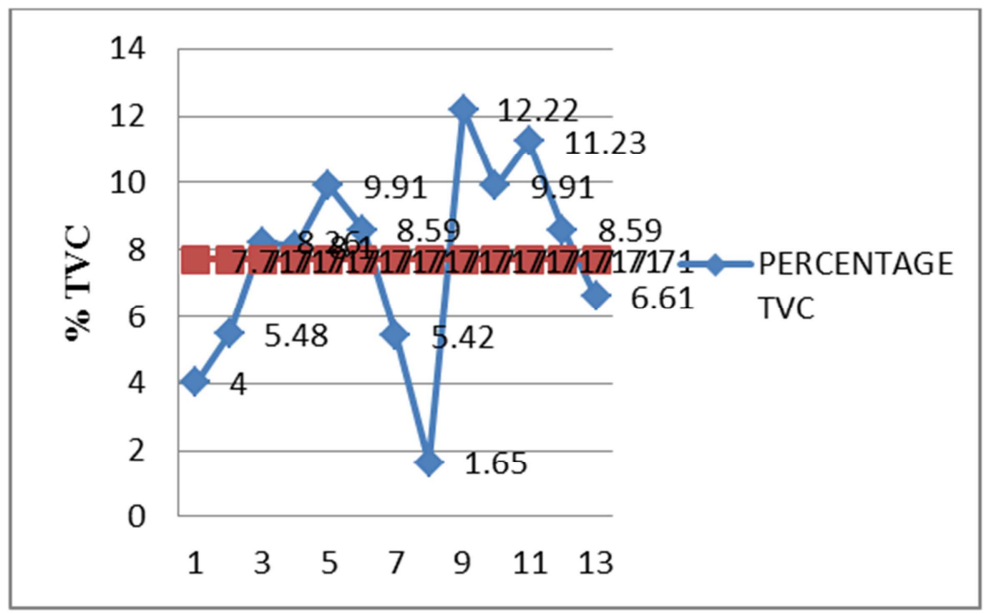

Figure 6. Percentage total viable count (TVC) of bacteria isolated from hand swab which ranges between $1.65-12.2$ colony forming unit (CFU) per ml.

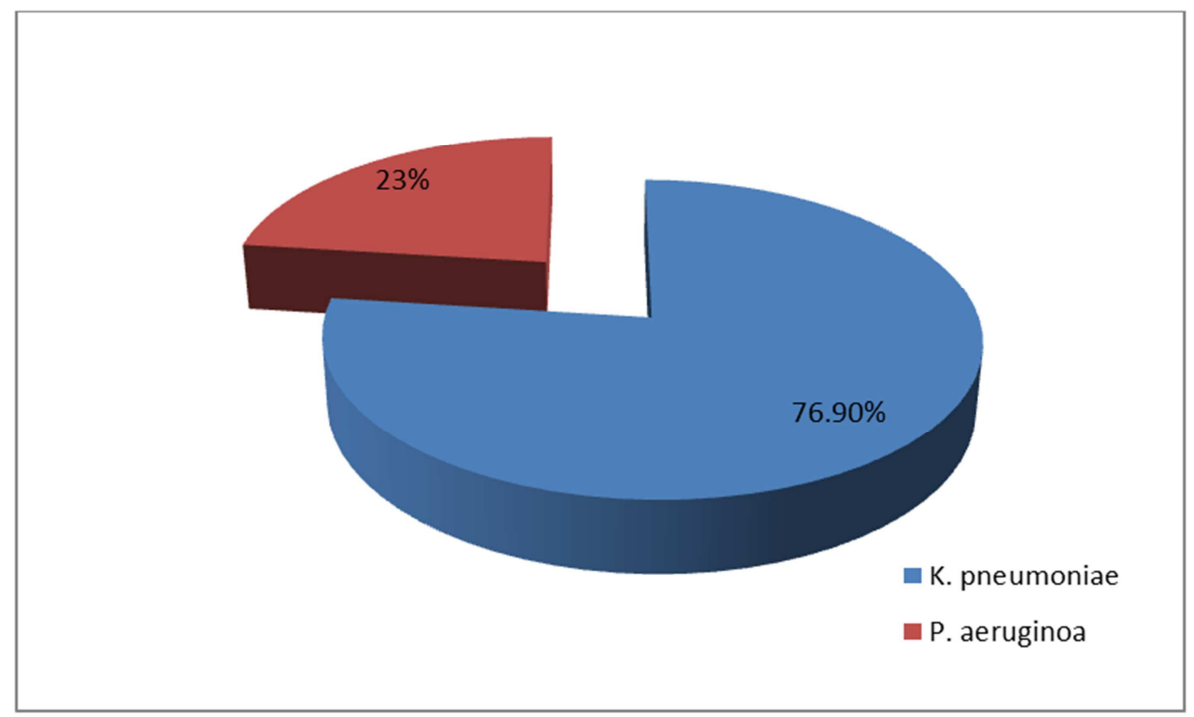

Figure 7. Relative occurrence of bacteria isolate in swab sample. 


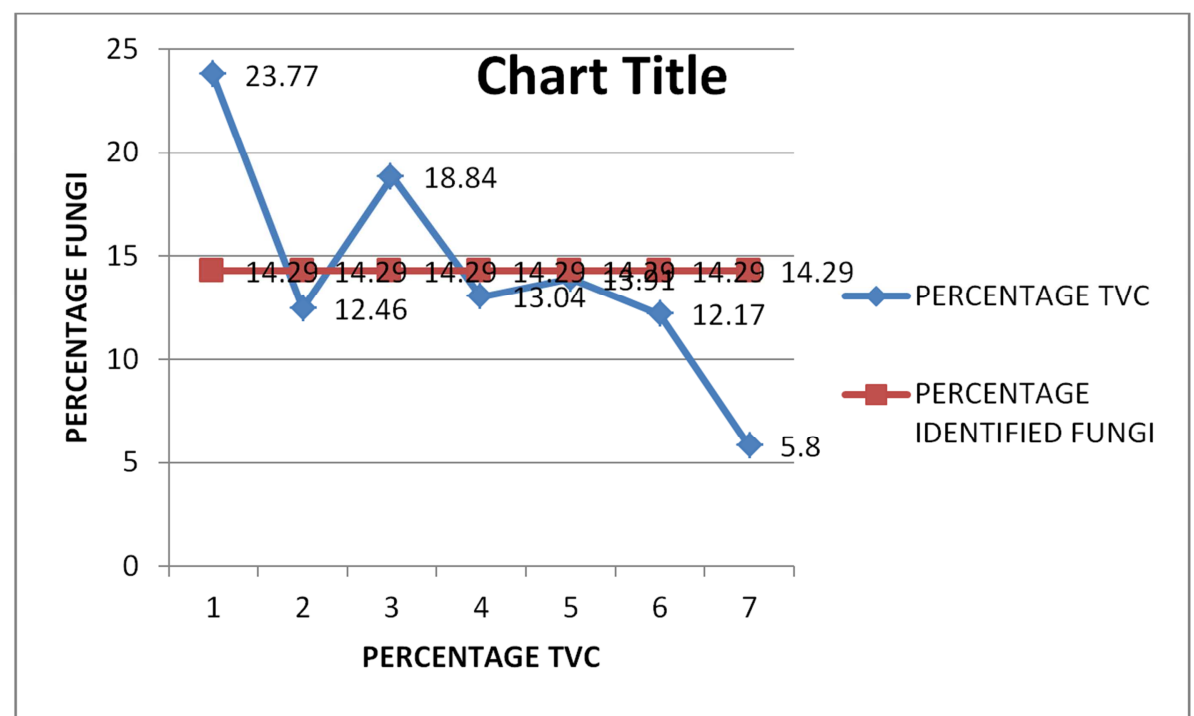

Figure 8. Percentage total viable count (TVC) of fungi isolated from hand swab which ranges between $5.8-23.77$ colony forming unit (CFU) per ml.

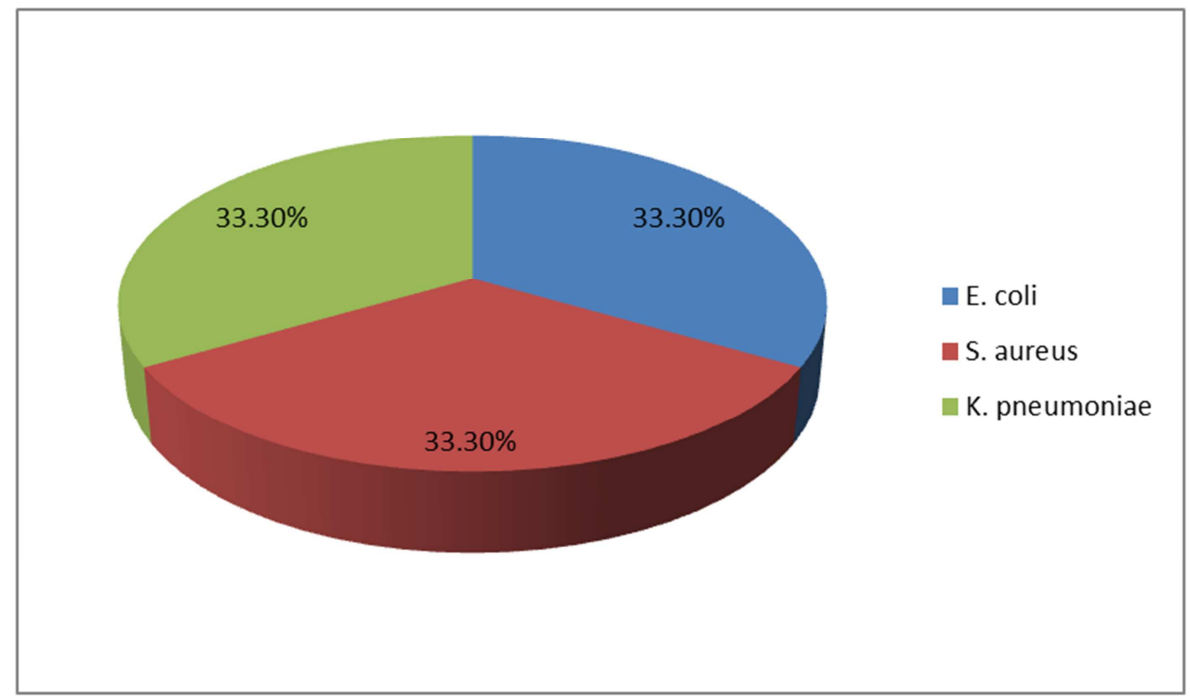

Figure 9. Relative occurrence of bacteria isolate in water sample.

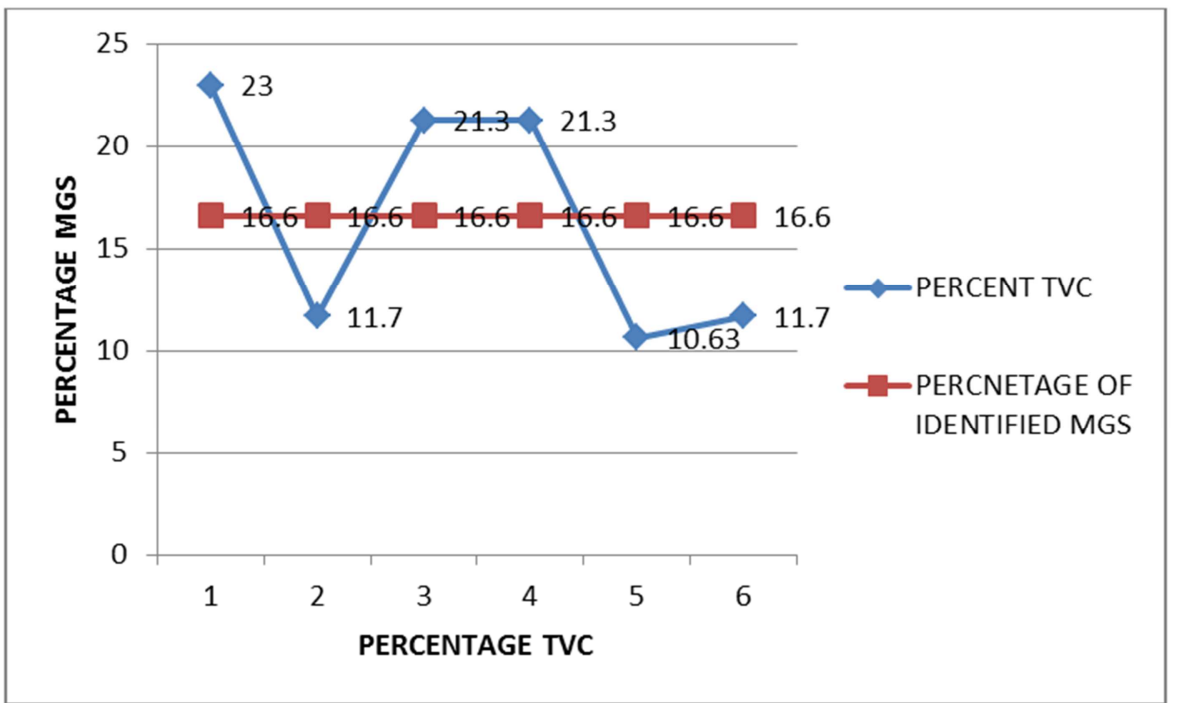

Figure 10. Percentage total viable count (TVC) of Bacteria isolated from water samples which ranges between 10.63 - 23 colon forming unit (CFU) per ml. 


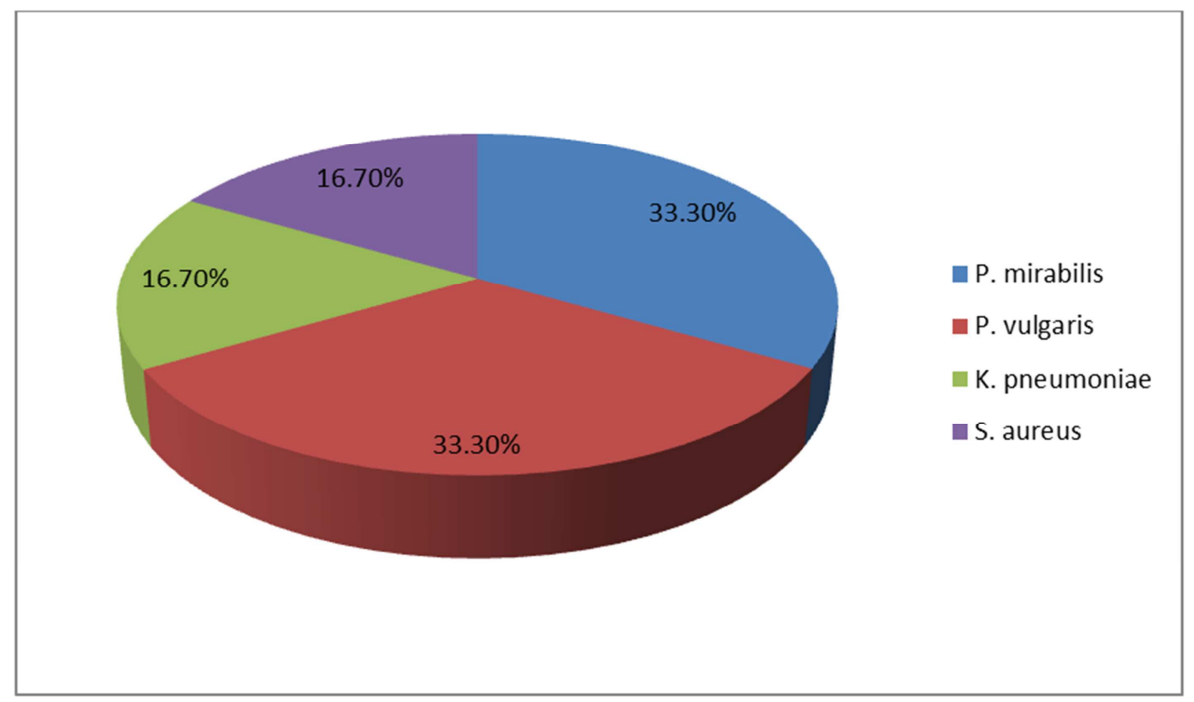

Figure 11. Relative occurrence of bacteria isolate in food samples.

Table 2. Antibiotic Sensitivity pattern of bacteria isolated from food, water and swab samples

\begin{tabular}{|c|c|c|c|c|c|c|c|c|c|c|c|c|c|c|}
\hline \multirow{3}{*}{$\begin{array}{l}\text { Antibiotics } \\
\text { Ofloxacin }\end{array}$} & \multirow{2}{*}{\multicolumn{2}{|c|}{$\begin{array}{l}\begin{array}{l}\text { Proteus } \\
\text { mirabilis }\end{array} \\
\begin{array}{l}\text { Zone size } \\
(\mathrm{mm})\end{array} \\
\end{array}$}} & \multirow{2}{*}{\multicolumn{2}{|c|}{$\begin{array}{l}\text { Staphylococcus } \\
\text { aureus } \\
\text { Zone size }(\mathrm{mm})\end{array}$}} & \multirow{2}{*}{\multicolumn{2}{|c|}{$\begin{array}{l}\begin{array}{l}\text { Escherichia } \\
\text { coli }\end{array} \\
\text { Zone size }(\mathrm{mm})\end{array}$}} & \multirow{2}{*}{\multicolumn{2}{|c|}{$\begin{array}{l}\text { Pseudomona } \\
\text { s aeruginosa } \\
\begin{array}{l}\text { Zone size } \\
(\mathrm{mm})\end{array} \\
\end{array}$}} & \multirow{2}{*}{\multicolumn{2}{|c|}{$\begin{array}{l}\begin{array}{l}\text { Klebsiellapneu } \\
\text { moniea }\end{array} \\
\text { Zone size }(\mathrm{mm})\end{array}$}} & \multirow{2}{*}{\multicolumn{2}{|c|}{$\begin{array}{l}\begin{array}{l}\text { Proteus } \\
\text { vulgaris }\end{array} \\
\text { Zone size }(\mathrm{mm})\end{array}$}} & \multirow{3}{*}{$\begin{array}{c}\text { \% R } \\
66.7\end{array}$} & \multirow{3}{*}{$\begin{array}{l}\% \mathrm{~S} \\
33.3\end{array}$} \\
\hline & & & & & & & & & & & & & & \\
\hline & $\mathrm{R}$ & 10 & $\mathrm{R}$ & 12 & $\mathrm{R}$ & 0 & $\mathrm{R}$ & 0 & $\mathrm{~S}$ & 26 & $\mathrm{~S}$ & 21 & & \\
\hline Perfloxacin & $\mathrm{R}$ & 14 & $\mathrm{R}$ & 0 & $\mathrm{~S}$ & 19 & $\mathrm{~S}$ & 19 & $\mathrm{~S}$ & 22 & $\mathrm{~S}$ & 21 & 33.3 & 66.7 \\
\hline Ciprofloxacin & $\mathrm{R}$ & 15 & $\mathrm{~S}$ & 22 & $\mathrm{~S}$ & 22 & $\mathrm{~S}$ & 21 & $\mathrm{~S}$ & 24 & S & 26 & 16.7 & 83.3 \\
\hline Ceftriaxone & $\mathrm{R}$ & 0 & $\mathrm{~S}$ & 22 & $\mathrm{R}$ & 8 & $\mathrm{R}$ & 0 & $\mathrm{~S}$ & 24 & $\mathrm{~S}$ & 23 & 50 & 50 \\
\hline Ceftazidime & $\mathrm{R}$ & 11 & $\mathrm{R}$ & 9 & $\mathrm{R}$ & 0 & $\mathrm{R}$ & 0 & $\mathrm{R}$ & 0 & $\mathrm{~S}$ & 20 & 83 & 16.7 \\
\hline Levofloxacin & $\mathrm{R}$ & 14 & $\mathrm{~S}$ & 22 & $\mathrm{~S}$ & 23 & $\mathrm{R}$ & 10 & $\mathrm{~S}$ & 22 & $\mathrm{~S}$ & 22 & 33.3 & 66.7 \\
\hline Streptomycin & $\mathrm{R}$ & 10 & $\mathrm{~S}$ & 17 & $\mathrm{R}$ & 0 & $\mathrm{~S}$ & 16 & $\mathrm{R}$ & 9 & $\mathrm{R}$ & 0 & 66.7 & 33.3 \\
\hline Ampicillin & $\mathrm{R}$ & 11 & $\mathrm{R}$ & 20 & $\mathrm{~S}$ & 16 & $\mathrm{R}$ & 0 & $\mathrm{R}$ & 10 & $\mathrm{R}$ & 9 & 83 & 16.7 \\
\hline Augmentin & $\mathrm{R}$ & 18 & $\mathrm{R}$ & 15 & $\mathrm{~S}$ & 24 & $\mathrm{R}$ & 0 & $\mathrm{R}$ & 8 & $\mathrm{R}$ & 14 & 83 & 16.7 \\
\hline Cloxacillin & $\mathrm{R}$ & 0 & $\mathrm{~S}$ & 25 & $\mathrm{R}$ & 0 & $\mathrm{R}$ & 0 & $\mathrm{R}$ & 10 & $\mathrm{R}$ & 0 & 83 & 16.7 \\
\hline Erythromycin & $\mathrm{R}$ & 12 & $\mathrm{~S}$ & 24 & $\mathrm{R}$ & 0 & $\mathrm{R}$ & 0 & $\mathrm{R}$ & 5 & $\mathrm{R}$ & 0 & 83 & 16.7 \\
\hline Tetracycline & $\mathrm{R}$ & 2 & $\mathrm{~S}$ & 20 & $\mathrm{~S}$ & 20 & $\mathrm{R}$ & 0 & $\mathrm{~S}$ & 26 & $\mathrm{R}$ & 11 & 50 & 50 \\
\hline Vancomycin & $\mathrm{S}$ & 18 & $\mathrm{~S}$ & 26 & $\mathrm{R}$ & 9 & $\mathrm{R}$ & 3 & $\mathrm{~S}$ & 21 & $\mathrm{R}$ & 1 & 50 & 50 \\
\hline$\% \mathrm{R}(\% \mathrm{~S})$ & 87 & & & & 50 & & 75 & & 43. & & 56. & .8) & & \\
\hline
\end{tabular}

R: Resistant, S: Sensitive.

\section{Discussion}

\subsection{Checklist}

Results from figure 1 revealed that during the transportation of foods only one hotel, hotel A (11.1\%) keep both cold and dry food at the proper temperature while the temperature of foods drops during transportation in the remaining hotels $(88.9 \%)$ this maybe as a result of absorption of moisture from environment due to delay in transportation. Cold food should be kept at $4^{\circ} \mathrm{C}$ and below and dry foods should be kept at $25^{\circ} \mathrm{C}$ to because microorganism thrives in food at temperature greater than $4^{\circ} \mathrm{C}$ for cold food.

Results from figure 2 revealed that $66.7 \%$ (6) of the hotels (A, B, C, D, E, G)store their cooked foods above raw foods to prevent drippings of raw foods into cooked foods in order to prevent cooked food from contamination while $33.3 \%$ (3) of the hotels (F, H, I) are not consistent with these arrangement of food. This is in contrast with a study in Ghana; the knowledge of street food vendors with regard to this was reportedly higher at $99 \%$ although only $27 \%$ practiced it (Donkor et al., 2009). In contrast, Campbell (2011) in his study found eighty nine (89\%) knowing how cooked foods are stored separately from raw foods and how foods are displayed to prevent contamination. No matter how safely foods are prepared, if it is not stored well and under right temperature, it can be predisposed to contamination. The higher the knowledge of the study in Ghana is due to the fact that it is an intervention. A lot of retrospective studies on cross contamination have investigated the cause of food

With regard to training, From figure 3, 44\% of the hotels (A, C, D, G) trained the food handlers before they were employed to the hotel and they were also given in-house 
training on food hygiene with HACCP excluded by the hotels after being employed every Mondays, $22.2 \%$ (B, E)of the hotels employ food handlers who have been trained before working with the hotel while the remaining hotels $(\mathrm{F}, \mathrm{H}$, I)make use of their receptionist as their food handler with no proper training in food hygiene. This implies that most of the hotels involved in the study a have knowledge on food hygiene but not on HACCP. This is in contrast with the work of Chukuezu (2010) revealed that only 5\% street food vendors had been exposed to food hygiene training.

From finings of figure 8, food thawing at room temperature instead of controlled areas such as cold room as required by the food handler was practiced by 88.9 (B-H) of the food handlers while $11.1 \%$ (A) of the hotel thaw food at refrigeration which is a safe environment for thawing food. All the hotels $11.1 \%$ (A) do not thaw frozen foods in the danger zone temperature for, it is thawed in the refrigerating temperature which is a safe temperature for thawing food or allowed to thaw in water which will take short time duration while $88.9 \%$ (B-I)thaw food at room temperature. Keeping meat and other food cold while it is defrosting is essential to prevent the growth of harmful bacteria. There is greater danger of bacterial growth and food spoilage for food thawed at room temperature, hence the best way to safely thaw meat and poultry is in the refrigerator. The microwave can also be used to defrost meat more rapidly. Food may also be thawed in cold water in a sink or container and this must be clean (United States Department of Agriculture, 2006).

\subsection{Hand Swab Analysis}

From figures 5, 6 and 7 it was revealed that the relative occurrence of bacteria in swab samples were (76.90\%) Klebsiella pneumoniae, (23\%) Pseudomonas aeruginosa with the percentage total viable count (TVC) of bacteria isolated from hand swab which ranges between $1.65-12.2 \times 10^{2}$ colony forming unit (CFU) per $\mathrm{ml}$ with the percentage total viable count (TVC) of fungi isolated ranging between 5.8 $23.77 \times 10^{2}$ colony forming unit (CFU) per $\mathrm{ml}$ and relative occurrence was $(100 \%)$ Candida albicans. The relative occurrence of microorganism is slightly similar but not conforming with the total viablecount in a study by (Okareh and Erhahon, 2014), Staphylococcus aureus (38.3\%), Staphylococcus epidermidis (21.7\%), Escherichia coli (16.7\%), Pseudomonas aeroginosa (15\%) and Streptococcus spp $(15 \%)$ amongst others were isolated with the total mean bacteria aerobic colony count $3.07 \times 10^{5}$ and also a study in Ilorin by Ajao and Atere (2009), similar microorganisms were isolated from the hand-swab of the food handlers working in canteens. The total viable count is in contrast with the study by Adolf et al., (2012) where the total count of yeast and mold ranging $7.5 \times 100-4.1 \times 10^{3} \mathrm{CFU} / \mathrm{g}$. This is an indication that food handlers have poor hand-washing practices. The presence of these microorganisms on the hands of the food vendors is a cause for concern as it could lead to transfer of microorganisms to the food and the utensils being used. The contaminated food, when consumed by the students it could cause food-borne illness.

\subsection{Water Analysis}

Figures 8 revealed that the relative occurrence of bacteria isolate in water was $(33.30 \%)$ E. coli, $(33.30 \%)$ S. aureus, $(33.30 \%)$ Klebsiella pneumomiae. This was in contrast with the work of Nawas et al., (2012) the relative occurrence of bacteria isolated in the sample were Salmonella spp was present in $46.67 \%$, Vibrio spp. was present in $53.33 \%$ of water, with total viable count $1.86 \times 10^{4}$ to $7.28 \times 10^{5} \mathrm{CFU} / \mathrm{g}$. Coliform organisms may not always be directly related to the presence of fecal contamination, the presence of coliforms in water suggested the potential presence of pathogenic enteric microorganisms such as Salmonella sp., Shigella sp., and Vibrio cholera (Zamberlan et al., 2008). According to (WHO, 2006), the bacteria that pose a serious disease risk whenever present in drinking water include Salmonella sp., pathogenic E. coli and Vibrio cholerae. The presence of $E$. coli in water is nearly always associated with recent fecal pollution and it is the preferred indicator organism for his purpose (Eaton et al., 2005). The presence of microorganism in the water sample could be due to, amongst other factors, contaminated water used to clean equipment and cutting/slicing machines leading to cross-contamination especially if used with raw foods, handlers not practicing proper sanitation and monitoring devices.

\subsection{Food Sample Analysis}

Results from figures 9 and 10 shows that the relative occurrence of bacteria isolate in food sample was $(33.30 \%)$ Proteus mirabilis, (33.30\%) Proteus vulgaris, (16.70\%) S. aureus $(16.70 \%),(16.70 \%)$ Klebsiella pneumonia and the total viable count were seen to be $1.7186 .82 \times 10^{2}$ colony forming unit (CFU) per ml. This does not conform with the study done by (Okareh and Erhahon, 2014) where the bacteria isolated were Staphylococcus aureus (30\%), Bacillus cereus $(25 \%)$ and Streptococcus faecalis $(8.3 \%)$ and total mean bacterial aerobic colony count was $3.52 \times 10^{4}$. The food samples from this study were found to be within the marginal aerobic colony count limits according to the International Commission for Microbiological Specification for Foods (ICSMF, 1978). This implies that, though the food samples were within limits of acceptable microbiological quality, there might have been possible hygiene problems either in the preparation of the food or in handling of the food. Different levels of total aerobic plate found since the amount and type of microbe grows in food are affected by natural properties of food such as $\mathrm{pH}$, water activity, environment, storage, processing method and including cross contamination from environment, plant, animal, soil or water as reported by Sperber and Doyle (2009).

\subsection{Antibiotic Sensitivity}

Results from table 2 revealed that Klebsiella pneumonia was resistant to 7 antibiotics (cefuroxime, ceftazidime, streptomycin, ampicillin, augumentin, cloxacillin, erythromycin) out of the 16 used and the percentage resistance was $43.8 \%$ and was sensitive to $9 \mathrm{M}$ (ofloxacin, 
perfloxacin, ciprofloxacin, ceftriaxone, levofloxacin, gentamicin, tetracyclin, nitrofuratoin, vancomycin) antibiotics with percentage sensitivity $56.3 \%$ to the antibiotics used. This is slightly similar to a study by Ahmed et al., (2014), Klebsiella spp. showed its highest resistance pattern against the antibiotic amoxycillin and the percentage of resistant isolates were $76.19 \%$. In case of Erythromycin $57.14 \%$ isolates were detected resistant, $28.57 \%$ Klebsiella spp. were observed to be resistant and Klebsiella spp. were susceptible to Ciprofloxacin, Gentamicin, Chloramphenicol, and Norfloxacin.

S. aureus was resistant to 6 antibiotics (ofloxacin, perfloxacin, ceftazidime ampicillin, augumentin, nitrofurantoin) out of the 16 that was used and the percentage resistance of $S$. aureus was $37.5 \%$ to the antibiotics used and was sensitive to 10 of the antibiotics (ciprofloxacin, ceftriaxone, cefuroxime, ceftazidime, levofloxacin, streptomycin, cloxacillin, erythromycin, gentamicin, tetracycline, vancomycin)the percentage sensitivity was $62.5 \%$ to the antibiotics used. This has a slight conformance with a study by Datta et al., (2012) where S. aureus was resistant to penicillin, ampicillin, amoxicillin, tetracycline, streptomycin, and neomycin. Percentage resistance of the $S$. aureus to penicillin, ampicillin, amoxicillin, streptomycin and neomycin were 85.71, 71.42, 100, 100, and 85.71, respectively.

According to the results of the study, E. coli was resistant to 8 antibiotics (ofloxacin, ceftriaxone, cefuroxime, ceftazidime, streptomycin, cloxacillin, erythromycin, vancomycin) out of the 16 that was used and the percentage resistance of $E$. coli to the antibiotics was in equilibrium with the sensitivity perfloxacin, ciprofloxacin, levofloxacin, ampicillin, augumentin, gentamicin, nitrofurantoin, levofloxacin) of $E$. coli to the antibiotics used (50\%). this was in agreement with a study by Teshale et al., (2015), where the sensitivity pattern of $E$. coli was sensitive to amoxicillin-clavulanic acid and tetracycline and this also agrees with the finding reported from Iran where $89.7 \%$ shiga toxin producing $E$. coli was resistant to tetracycline. In agreement with the present finding, study done in Nigeria found that $91.4 \%$ EHEC $0157: \mathrm{H} 7$ were resistant to tetracycline.

Klebsiella pneumonia was resistant to 7 antibiotics (cefuroxime, ceftazidime, streptomycin, ampicillin, augumentin, cloxacillin, erythromycin) out of the 16 used and the percentage resistance was $43.8 \%$ and was sensitive to 9 (ofloxacin, perfloxacin, ciprofloxacin, ceftriaxone, levofloxacin, gentamicin, tetracyclin, nitrofurantoin, vancomycin) antibiotics with percentage sensitivity $56.3 \%$ to the antibiotics used. This is in line with the work of Adesetan, (2013), where K. pneumonia was resistant to pefloxacin and cotrimoxazole and Klebsiella $s p$ shows high sensitivity to amoxycillin/clavulanic acid.

Pseudomonas aeriginosa was resistant to 12 antibiotics (ofloxacin, ceftriaxone, cefuroxime, ceftazidime, levofloxacin, ampicillin, augumentin, cloxacillin, erythromycin, tetracycline, nitrofurantoin) out of the 16 that was used and the percentage resistance was $75 \%$ and was sensitive to 4 (perfloxacin, ciprofloxacin, streptomycin, vancomycin) antibiotics with percentage sensitivity $25 \%$ to antibiotics used.

Proteus vulgaris was resistant to 9 antibiotics (cefuroxime, streptomycin, ampicillin, augumentin, cloxacillin, erythromycin, gentamicin, tetracycline, vancomycin) out of the antibiotics used and the percentage resistance was $56.8 \%$ and was sensitive to 7 (ofloxacin, perfloxacin, ciprofloxacin, ceftriaxone, ceftazidime, levofloxacin, nitrofurantoin) with percentage sensitivity $43.8 \%$ to the antibiotics used. As studies conducted elsewhere showed the importance of Proteus as an indicator of unhygienic food processing practice (Tambekar et al., 2009) the role of Proteus as food pathogen should be further investigated.

\section{Conclusion}

In conclusion, the presence of drug resistant bacterial species in hotel food samples is a matter of serious threat for public health concern, which is a hurdle to develop a healthy and safe living environment for human. Spreading of antibiotic resistant pathogens is making the situation critically complex to treat diseases. Uncontrolled and drastic consumption of some common antibiotics influences the spreading of antibiotic resistant bacteria (Hillier et al., 2002). Abuse of antibacterial like self -prescription is another significant cause for spreading the antibiotic resistant properties into bacteria.

Majority of the hotel owners are not aware of HACCP system in formal set-ups. Some of the hotels especially the standard ones put in some parts of HACCP programme in their food production procedures without being aware its part of the HACCP programme and while the substandard ones while the substandard hotels were unsure of what it was or how to apply the principles to their operation. There appeared to be challenges to implementing these programs and efforts need to be made to overcome the challenges. There is little knowledge on HACCP as a strategy for quality control among the managers and staff of the hotels. The management of the hotel does not observe adequate precautions in the some of the food processing procedures and therefore programs and materials related to HACCP need to be presented in a practical, realistic and step by step manner. A key focus area would be on motivating employees to follow standard operating procedures related to food safety. Most of the food wastes in th are poorly managed, utensils and crockery are fairly cleaned because not all hotels use hot water in cleaning their utensils, kitchen and dining floor are well-cleaned. Non-availability of hot water for customers to wash their hands was noted in some hotels. Most customers are keen on hygiene standards because this was quite evident in some hotels where many customers were found in the clean environment. Just like street-vended foods may pose significant public health problems, hotel foods can follow suit if poorly handled. One of the key findings of the WHO survey of street-vended foods was that infrastructure 
developments were relatively limited in relation to access to portable water, toilets, and refrigeration, washing and waste disposal facilities.

At the end of the HACCP assessment, the investigator organized training on HACCP for the food handlers, F and B managers to orientate them about the HACCP procedures.

The following recommendations were made;

The environmental health authorities should extend their periodical spot checks and random sampling together with the sensitization on food safety standards to the Staff and managers of the food establishments. They should also do thorough checks on how food is received, stored, issued, prepared and served to the customers. The current spot checks they do now are low.

1) The Ministry of Health through the public health authorities should educate adequately all hotel owners, managers, staff, and other stakeholders on system implementation.

2) The environmental health authorities should also have a monitoring system for food-borne outbreaks associated with specific premises.

3) Proper training will ensure correct passage of information to the employees and customers and therefore increase participation on HACCP implementation which is an expensive exercise to begin with but a cost saving in the long run to the sector.

4) The environmental health authorities should also take the challenge and not leave the catering colleges alone to be the only source of HACCP information.

5) More research needs to be done by all stakeholders on how best HACCP can be fully applied in all kinds of hotels and a fully trained, well-prepared team should be in place to initiate, conduct, monitor and evaluate the HACCP process in the hotels.

6) The environmental health authority should inform consumers through posters, the media and publicity campaigns about common food safety measures. Consumers should also be informed of their responsibility in ensuring that they do not contaminate, dirtily or litter cooking environment.

\section{References}

[1] Addo, K. A., Mensah, G. I., Bonsu, C. and Akyeh, M. 2007. Food and its preparation condition in Hotels in Accra, Ghana: A Concern for Food Safety. African Journal of Food, Agriculture Nutrition and Development 7(5): 1-12.

[2] Adedoyin, O. T.; Ojuawo, A.; Adesiyun, O. O.; Mark, F.; Anigilaje, E. A. Poisoning due to yam flour consumption in five families in Ilorin, central Nigeria. West Afr. Med. J. 2008, $27,41-43$.

[3] Adeleke, S. I. Food poisoning due to yam flour consumption in Kano (Northwest) Nigeria Online J. Health Allied Scs. $2009,8,10$.

[4] Afolaranmi TO, Hassan ZI, Bello DA, Tagurum YO, Minner CR, Sule HM. Foodsafety: an assessment of the safety and hygienic condition of food premises in boarding secondary schools within Jos metropolis, Plateau state, Nigeria. Jos J Med. 2012;6 (3):10-15.

[5] Ahmed T M, Entrepreneurs of the Streets: an Analytical Work on the Street Food Vendors of Dhaka City; International Journal of Business and Management, 2009, Vol.4, No.2, Feb, 2009.

[6] Aibor, M. S. and Olorunda, J. O. (2006). Environmental Health in the 21st Century for Professional Students. Lagos. Divine Favour Publishers.

[7] Ajao, A. T. and Atere, T. G. (2009). Bacteriological Assessment and Hygienic Standard of Food Canteens in Kwara State Polytechnic, Ilorin, Nigeria. African Scientist 10(3):173-180.

[8] Akunyili D. 20,000 die annually of food poisoning accessed from www.nigeriabestforum.com website on 8th Mar. 2011.

[9] Amref, Kenya, (1982): Food borne Disease Outbreaks Surveillance. Nairobi: Government Printer. 54-60.

[10] Anant AT, Anjali PK. Assessment of personal hygiene of canteen workers of government medical college and hospital, Solapur, India. Nat J of Comm Med. 2011 Oct-Dec; 2(3):448.

[11] Andrews Sudhir (2000) Food \& Beverage Management, Tata McGraw- Hill Publishing Co. Ltd, New Delhi.

[12] Anita, T.(2002). Food Technology; an Introduction. Oxford. Oxford University Press.

[13] Bark Seung-Hee, Ham II Sunny and yang sun (2006), cross cultural comparison of fast food restaurant selection criteria between Korean and Filipino college students,

[14] Birchfield, J. C. (2008). Design and Layout of Foodservice Facilities. 3rd Ed. New Jersey. John Wiley \& sons, inc.

[15] Byran F. L., (1992): Hazard Analysis Critical Control Point Evaluation. A guide to identifying hazards and assessing risks associated with food preparation and storage-Geneva, 1211.

[16] [14]Campbell M. E., C. E. Gardner, J. J. Dwyer, S. M. Isaacs, P. D. Krueger, J. Y. Ying. 1998. Effectiveness of public health interventions in food safety: a systematic review. Canadian Journal of Public Health 89(3):197-202. catering industry in Ankara (Turkey)", Food Control, Vol. 19, pp. 9-15.

[17] Chen, Y., Jackson, K. M., Chea, F. P. and Schaffner, D. W. 2001. Quantification and Variability Analysis of Bacterial Cross-Contamination Rates in Common Food Service Tasks. Journal of Food Protection 64(1): 72-80.

[18] Chukwuezi CO (2010). Food Safety and Hygienic Practices of Street Food Vendors in Owerri, Nigeria. Studies Soc. Sci. $1(1): 50-57$.

[19] Clark, D. S. (1965): Method of Estimating the Bacteria population of surfaces. Canadian J. Microbiol11:407-413.

[20] Clark, R. A., Hartline, M. D., and Jones, K. C. (2009); The effects of leadership style on hotel employees' commitment to service quality. Cornell Hospitality Quarterly, Vol. 50, No. 2, pp. 209-231.

[21] Clayton, D. A. and Griffith, C. J. (2004). Observation of Food Safety Practices in Catering Using Notational Analysis. British Food Journal. Vol.106. No. 3, pp 211-227. 
[22] Corlett, D. A., Jr., (1998): HACCP User's Manual. Gaithersburg, MD: Aspen Press.

[23] Darko, S., Mills-Robertson, F. C. and Wireko-Manu, F. D., evaluation of some hotel kitchen staff on their knowledge on food safety and kitchen hygiene in the Kumasi Metropolis: International Food Research Journal 22(6): 2664-2669 (2015).

[24] Donkor, S. E., Kayang, B. B., Quay, J., \&Akyeh, M. L. (Nov. 2009). Application of the WHO keys of safer food to improve food handling practices of food vendors in poor resource community in Ghana. International Journal of Environment Research and Public Health, 6(11).

[25] Eastham, J. F., Sharples, L., Ball, S. D. (Eds) (2001). Food Supplies Chain Management. Issues for the Hospitality and Retail Sector. Oxford. Elsevier Butterworth Heinemann.

[26] Eaton, A. D., Clesceri, L. S., Rice, E. W., Greenberg, A. E. and Franson, M. A. H. 2005. Standard Methods for the Examination of Water and Wastewater. 21st Edn., American Public Health Association, USA., ISBN-10: 0875530478 http://refhub.elsevier.com/S0956-7135(14)00370-3/sref13.

[27] Eves Anita \& Dervisi Panagiota (2005) 'Experiences of the implementation and operation hazard analysis critical control point in the food service sector, International journal of hospitality management, volume 24 , issue 1 .

[28] FAO/WHO (2002): Sharing information on national experiences in the general field of risk management (Paper submitted by the delegation of France) Global forum of food safety regulators (Agenda item 4. 4) 1- 4.

[29] Fatiregun, A. A.; Oyebade, O. A.; Oladokun, L. Investigation of an outbreak of food poisoning in a resource-limited setting. Trop. J. Health Sci. 2010, 17, 1117-4153.

[30] Food and Agricultural Organization (FAO). (1997). Essential Safety Requirements for Street-Vended Foods, (revised edition), FAO Food and Nutrition Paper.

[31] Fosket, D. and Ceserani, V. (2007). Ceserani and Kinton's "The Theory of Catering"(11 th Ed). London. Hodder Arnold.

[32] GoK (2005): District survey office, Ministry of lands, Nairobi, Kenya.

[33] GoK (2005): Ministry of Health Annual Medical Report (805).

[34] Hilton, J. (2002). Reducing Foodborne Disease: Meeting the Food Standards Agency'sTargets. Nutrition and Food Science. Vol. 32. Iss: 2, pp46-50

[35] ICMSF. 1978. Microorganisms in Foods 1 - Their significance and methods of enumeration, $2^{\text {nd }}$ edition. University of Toronto, Toronto.

[36] Ilboudo and A. S. Traoré (2006): Hygienic status assessment of dishwater, utensils, hands and pieces of money in street foods vending sites in Ouagadougou; Burkina Faso. African. Journal. Biotechnology. 5: 1107-1112.

[37] Indian Journal of nutrition and dietetics. 25, 197-199.

[38] International journal of Hospitality Management, volume 25, issue 4, pp. 683-698.

[39] Jay JM. 2000. Modern food microbiology. 6th ed. Gaithersburg (MD): Aspen. p 679.
[40] Jones, S. L., Parry, S. M., O'Brien, S. J. and Palmer, S. R. (2008b), "Operational Practices Associated with FoodBorne Disease Outbreaks in the Catering Industry in England and Wales", Journal of Food Protection, Vol. 3, pp.1659-1665.

[41] Kaul, M and Agarwal, G. (1988) Microbial load of common chat products. The Indian Journal of nutrition and dietetics.25, 197-199.

[42] Leach, J., Mercer, H., Stew, G. and Denyer, S. (2001). Improving food hygiene standards- a customer focused approach. British Food Journal Vol.103. No.4, pp.238-252.

[43] Mattila, L., Siitonen, A., Kyronseppa H. et al. Risk behaviour for travellers' among Finish travelers. J Travel Med. 1995; 2:77-84.

[44] McLauchlin, J. and Little, C. (Eds) (2007) Hobbs ${ }^{\text {ee Food }}$ Poisoning and Food Hygiene. ( $7^{\text {th }}$ Ed) London. Hodder Arnold.

[45] Mensah, P., Yeboah-Manu, D., Owusu-Darko, K.,\& Ablordey, A. (2002). Street Food in Accra, Ghana; How Safe Are They?

[46] Merry, A. F. T. E., Miller, G., Findon, C. S. and Neff, S. P. W. 2001. British. Journal of. Anaesthesia 87: 291-294.

[47] Mohini, S. (2004). Institutional Food Management. New Delhi. New Age International (P) Ltd.

[48] Morgan, J. L. (2006). Culinary Creation. An Introduction to Food Service and World Cuisine. Oxford. ButterworthHeinemann.

[49] Morris JG. 2000. The effect of redox potential. In: Lund BL, Baird-Parker TC, Gould GW, editors. The microbiological safety and quality of food. Volume 1. Gaithersburg (MD): Aspen. p 235-50.

[50] Mortlock, M. P., Peters, A. C. and Griffith, C. (2000). A National Survey of Food Hygiene Training and Qualification Levels in the UK Food Industry. International Journal of Environmental Health. Vol. 10, pp. 111-23.

[51] Mossel DAA, Thomas G. 1988. Securitemicrobioligique des plats prepares refrigeres: recommendations en matiered' analyse des risques, conception et surveillance du processus de fabrication.

[52] Mosupye, and holy (1999) Microbiological quality and safety of ready to-eat street- vended foods in Johannesburg, South Africa. J Food Prot62:1278-1284.

[53] Murat Bas, Azmi Safak Ersun\& Gokhankiranc (2000), knowledge, attitudes and practices concerning food safety issues among food handlers in Turkey; Health sciences faculty, Department of nutrition and dietetics, Barkent university, Turkey.

[54] National Committee for Clinical Laboratory Standards (NCCLS). Performance standards for antimicrobial susceptibility testing, 12th international supplement; 2004; 62-78, 2004. NEHPR,(2007). National Environmental Health Practice Regulations. (Revised). Honorable Minister of the Federal Ministry of Environment and Housing, Abuja.

[55] Nigerian Tourism Development Corporation (NTDC) (2001). Standard for National Classification and Grading of Hotels and Other Serviced Accommodations in Nigeria. 1 ' 1 Ed. Abuja: Nigerian Tourism Development Corporation. 
[56] NIST National Institute of Standards and Technology. 2000. Uniform laws and regulations in the areas of legal metrology and engine fuel quality [as adopted by the 84th National Conference on Weights and Measures 1999]. 2000 ed. Gaithersburg (MD): U. S. Dept. of Commerce, Technology Administration, National Institute of Standards and Technology. Uniform open dating regulation; p 117-22.

[57] Okareh O. T., Erhahon O. O., Microbiological Assessment of Food and Hand-Swabs Samples of School Food Vendors in Benin City, Nigeria (2015).

[58] Olsen, S. J., Machinnon, L. C., Goulding, J. S., Bean, N. H., Slutsker, L. (2000) surveillance for Food-borne Disease outbreaks - United States, 1993-1997. Morbidity and Mortality Weekly Report. Vol. 49. No 1, pp.1-51. Organisation. ISSN0042-9686 Version Impresa.

[59] Osagbemi, G.; Abdullahi, A.; Aderibigbe, S. Knowledge, attitude and practice concerning food poisoning among residents of Okene Metropolis, Nigeria. Res. J. Soc. Sci. 2010, $1,61-64$.

[60] Oyemade, A.; Omokhodion, F. O.; Olawuyi, J. F.; Sridhar, M. K. C.; Olaesha, I. O. Environmental and personal hygiene practices: Risk factors for diarrhea among children of Nigerian market women. J. Diarrheal Dis. Res. 1998, 16, 241247.

[61] Policy Guidelines on Sanitary Inspection of Premises." Developed by Federal Ministry of Environment, Abuja, January 2005. on 61 (supplement 4):1531-1534).

[62] Rane, S. (2011) Street Vended Food In Developing World: Hazard Analyses.

[63] Rippington, N. (2008). Professional Chef 1Level Diploma. UK. Cengage Learning EMEA.

[64] Sari, H. and Ari, L (2006) a guide to Sanitation and Hygiene for those working in developing countries.

[65] Schmalleger, F. (2006). Criminal Law Today. Online Encyclopedia of Criminal Justice. cjencyclopedia. com

[66] Seaman Phillip and Eves Anita (2005) The management of food safety-the role of food hygiene training in the U. K service sector, International journal of hospitality management, volume 24 , issue,

[67] Smelt JPPM, Raatjes JGM, Crowther JC, Verrips CT. 1982. Growth and toxin formation by Clostridium botulinum at low pH values. J Appl Bacteriol 52:75-82.

[68] Sperber, W. H. and Doyle, P. M. 2009. Compendium of the microbiological spoilage of foods and beverages. NewYork: Springer.

[69] Subratty, A. H., Beeharry, P. and Chan Sun, M. (2004). A Survey of Hygiene Practices Among Food Vendors in Rural Areas in Mauritius. Nutrition and Food Science. Vol.34. Iss. 5, pp. 203-205.
[70] Subratty, A. H., Beeharry, P. and Chan Sun, M. (2004). A Survey of Hygiene Practices Among Vendors in Rural Areas in Mauritius. Nutrition and Food Science. Vol.34. Iss.5, pp. 203-205.

[71] Steffen R, Collard F, Tornieporth N, et al. Epidemiology, etiology and impact of travellers' diarrhea in Jamaica. JAMA 1999; 281: 811-817. 1998-2000 J. Travel Med. 2003; 10:7985.

[72] T Nawas, R M Mazumdar, S Das, M N Nipa, S Islam, H R Bhuiyan and I Ahmad, Microbiological Quality and Antibiogram of E. coli, Salmonella and Vibrio of Salad and Water from Restaurants of Chittagong, 2012, J. Environ. Sci.\& Natural Resources, 5(1): 159 - 166.

[73] Tambekar DH, Jaiswal VJ, Dhanorkar DV, Gulhane PB, Dudhane MN. Microbial Quality and Safety of Street Vended Fruit Juices: A Case Study of Amravati City. Internet J Food Saf. 2009; 10:72-76.

[74] Teshale Worku, AyalewJejaw, Subbaram Kannan, Beyene Wondafrash, isolation and Antimicrobial Sensitivity Patterns of Enteric Bacterial Pathogens from Asymptomatic Food Handlers, Jimma, Ethiopia, American Journal of Health Research 2015; 3(6): 399-406 Published online January 4, 2016 (http://www.sciencepublishinggroup.com/j/ajhr).

[75] Tricket, J. (2001). The Prevention of Food Poisoning. 4th Ed. Nelson Thornes Ltd. UK

[76] United States Department of Agriculture, Fact Sheets on Safe Food Handling, 2006.

http://www.fsis.usda.gov/FactSheets/Smoking_Meat_and _ Poultry/index.asp

[77] WHO (1989). Health Surveillance And Management Procedures For Food-Handling Personnel. WHO Technical Report Series 785.

[78] WHO (2010). Five Keys to safer food.www.who.int/food safety/consumer/5keysVisited 01.04.2010

[79] WHO/UNICEF Joint Monitoring Programme (JMP) for Water and Sanitation. Available online: http://www.unicef.org/wash/index_documents.html (accessed on 17 May 2013)

[80] Willey, I. M., Sherwood, L. M and Woolverton, C. J (2008). Prescott, Harley and Klein's Microbiology.7th ed, NYMcGraw Hill International. pp 122-142.

[81] Wogu, M. D., Omoruyi, M. I., Odeh, H. O. and Guobadia, J. N. (2011). Journal of Microbiology and Antimicrobials. Vol.:3 (2): 29-33.

[82] World Health Organization (2007). Fact sheet No 237. Food Safety and Foodborne Illness. Google internet, November, 2008 .

[83] World Health Organization (WHO). Global Burden of Disease; WHO: Geneva, Switzerland, 2009., (accessed on 17 May 2013). 